\title{
The Caloosahatchee River Estuary: A Monitoring Partnership Between Federal, State, and Local Governments, 2007-13
}

\section{By Eduardo Patino}

The tidal Caloosahatchee River and downstream estuaries (fig. 1) have substantial environmental, recreational, and economic value for southwest Florida residents and visitors. Modifications to the Caloosahatchee River watershed have altered the predevelopment hydrology, thereby threatening the environmental health of estuaries in the area (South Florida Water Management District, 2014). Hydrologic monitoring of the freshwater contributions from tributaries to the tidal Caloosahatchee River and its estuaries is necessary to adequately describe the total freshwater inflow and constituent loads to the delicate estuarine system.

From 2007 to 2013, the U.S. Geological Survey (USGS), in cooperation with the Florida Department of Environmental Protection (FDEP) and the South Florida Water Management District (SFWMD), operated a flow and salinity monitoring network at tributaries flowing into and at key locations within the tidal Caloosahatchee River (fig. 1). This network was designed to supplement existing long-term monitoring stations, such as W.P. Franklin Lock, also known as S-79 (fig. 2), which are operated by the USGS in cooperation with the U.S. Army Corps of Engineers, Lee County, and the City of Cape Coral. Additionally, a monitoring station was operated on Sanibel Island from 2010 to 2013 (fig. 1) as part of the USGS Greater Everglades Priority Ecosystem Science initiative and in partnership with U.S. Fish and Wildlife Service (J.N. Ding Darling National Wildlife Refuge). Moving boat water-quality surveys throughout the tidal Caloosahatchee River and downstream estuaries began in 2011 and are ongoing. Information generated by these monitoring networks has proved valuable to the FDEP for developing total maximum daily load criteria, and to the SFWMD for calibrating and verifying a hydrodynamic model. The information also supports the Caloosahatchee River Watershed Protection Plan (South Florida Water Management District, Florida Department of Environmental Protection, and Florida Department of Agriculture and Consumer Services, 2009).

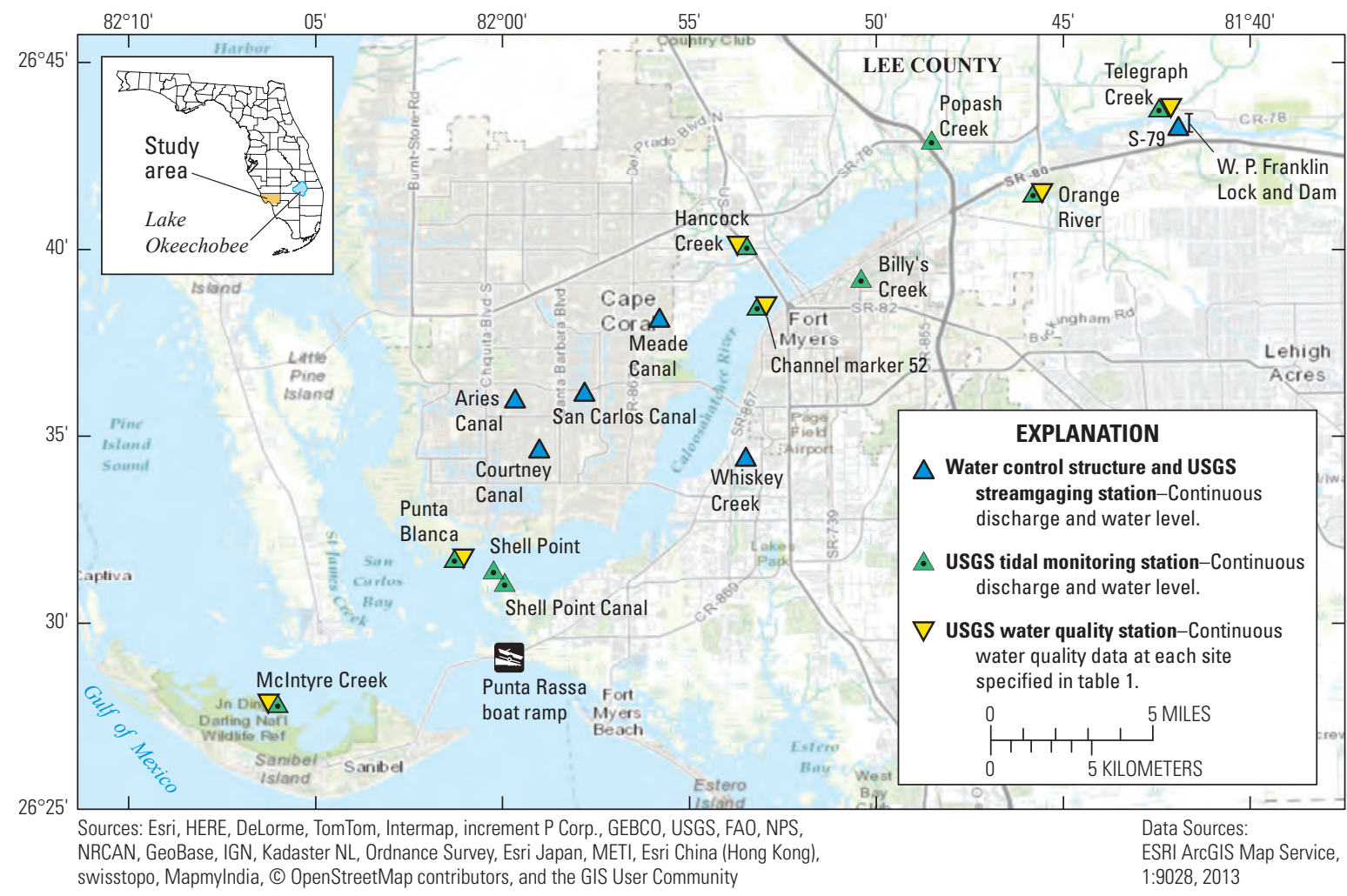

Figure 1. Caloosahatchee River Estuary monitoring stations. 


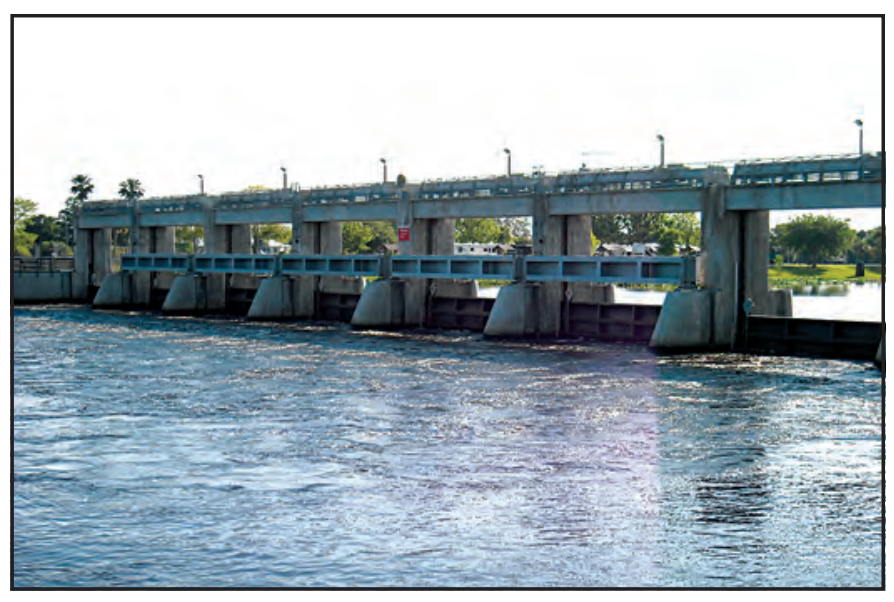

Figure 2. Control structure S-79 at Franklin Locks.

\section{Continuous Monitoring Networks}

Each monitoring station within the tidal Caloosahatchee River, its tributaries, and downstream estuaries required a variety of techniques and methods to collect, analyze, and verify the hydrologic data obtained during the monitoring period. The periods of record for the data recorded at each monitoring station are listed in table 1.

Monitoring stations at W.P. Franklin Lock (S-79), Whiskey Creek, Aries Canal, Meade Canal, San Carlos Canal, and Courtney Canal measure continuous flow and water levels at control structures with vertical lift gates, broad-crested weirs, or both. The techniques and methods used to collect, process, and publish data from these monitoring stations are described in Rantz and others (1982).

At tidally affected and open-channel sections of the Caloosahatchee River and its tributaries, use of the index velocity method was required to accurately determine flow. Index velocity meters were therefore installed at additional stations located at Telegraph Creek, Orange River, Popash Creek, Billy's Creek, Caloosahatchee River at Channel Marker 52, Hancock Creek, Caloosahatchee River at Shell Point, Shell Point Canal, and McIntyre Creek (fig. 3). The techniques and methods used to collect, process, and publish data from these monitoring stations are described in Levesque and Oberg (2012).

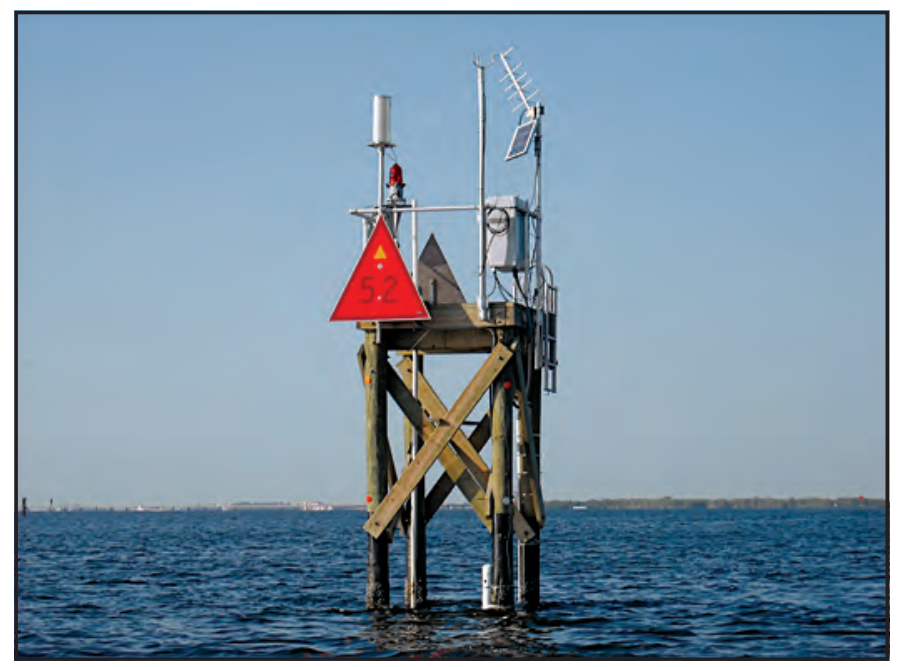

Figure 3. Caloosahatchee River at the marker 52 monitoring station.
Tributary flows into the tidal Caloosahatchee River can vary seasonally in response to local rainfall patterns. Conversely, discharge at S-79 is based on operational schedules for the control structure and the regulation of water levels at Lake Okeechobee. Discharge data from 2007 to 2013 indicate that S-79 freshwater inflow to the tidal Caloosahatchee River is substantially greater than the total inflow from all monitored tributaries (fig. 4).

The continuous water-quality monitoring network within the tidal Caloosahatchee River and its tributaries included the collection of salinity and temperature data for locations and periods listed in table 1 . The techniques and methods used to collect, process, and publish data from these monitoring stations are provided in Wagner and others (2006).

\section{Periodic Near-Surface Water-Quality Surveys}

At least six times per year, near-surface water-quality surveys of the tidal Caloosahatchee River and downstream estuaries were completed to produce water-quality maps (Booth and others, 2014). These surveys typically began at the boat ramp near Punta Rassa, entered San Carlos Bay, circled around Pine Island, and ended upstream along the Caloosahatchee River near the W.P. Franklin Lock (S-79) (fig. 1).

During the surveys, concurrent water-quality sensor and coordinate data were recorded as the boat traveled throughout the study area. A pump system brought near-surface water onboard and into the flow-through cell containing the waterquality sensors. Salinity, temperature, dissolved oxygen, $\mathrm{pH}$, and turbidity data were recorded at 5-second intervals. A salinity map was generated from a water-quality survey on August 1,2013 , during a period of large freshwater releases at S-79 (fig. 5). The techniques and methods used to calibrate the sensor prior to each survey and post-process the data have been published by Wagner and others (2006), Soderqvist and Patino (2010), and Booth and others (2013).

\section{Products and Data Availability}

Data and information published as a result of these collaborative monitoring networks are available to resource managers, researchers, and the public through the USGS National Water Information System (NWIS) and South Florida Information Access (SOFIA) Web sites. Fifteen-minute and daily time-series data are available either at the NWIS (http://waterdata.usgs. gov/fl/nwis/sw/) or SOFIA (http://sofia.usgs.gov/projects/index. php?project_url=flow_caloo) Web sites. Data searches can be made by station name or station number (table 1). Maps and data for near-surface water-quality surveys can be retrieved from the SOFIA Web site at http://sofia.usgs.gov/exchange/ ding_wqs/index.php.

\section{References Cited}

Booth, A.C., Knight, T.M., and Soderqvist L.E., 2013, Nearsurface water-quality surveys of the Caloosahatchee River and downstream estuaries, Florida, USA: U.S. Geological Survey Data Release, http://dx.doi.org/10.5066/F70863BC. 


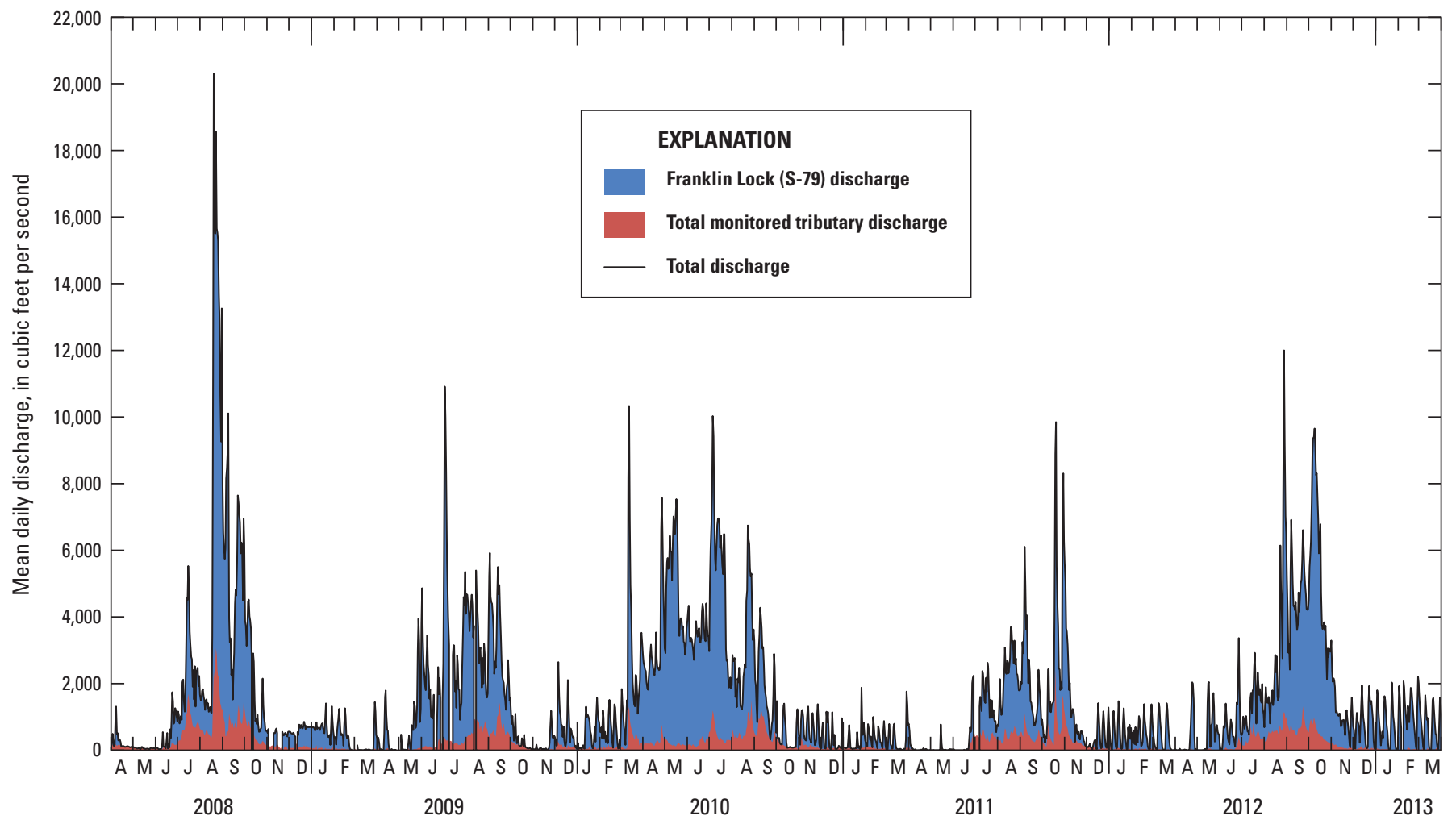

Figure 4. Total monitored discharge into the tidal Caloosahatchee River, contributions from control structure S-79, and contributions from monitored tributaries.

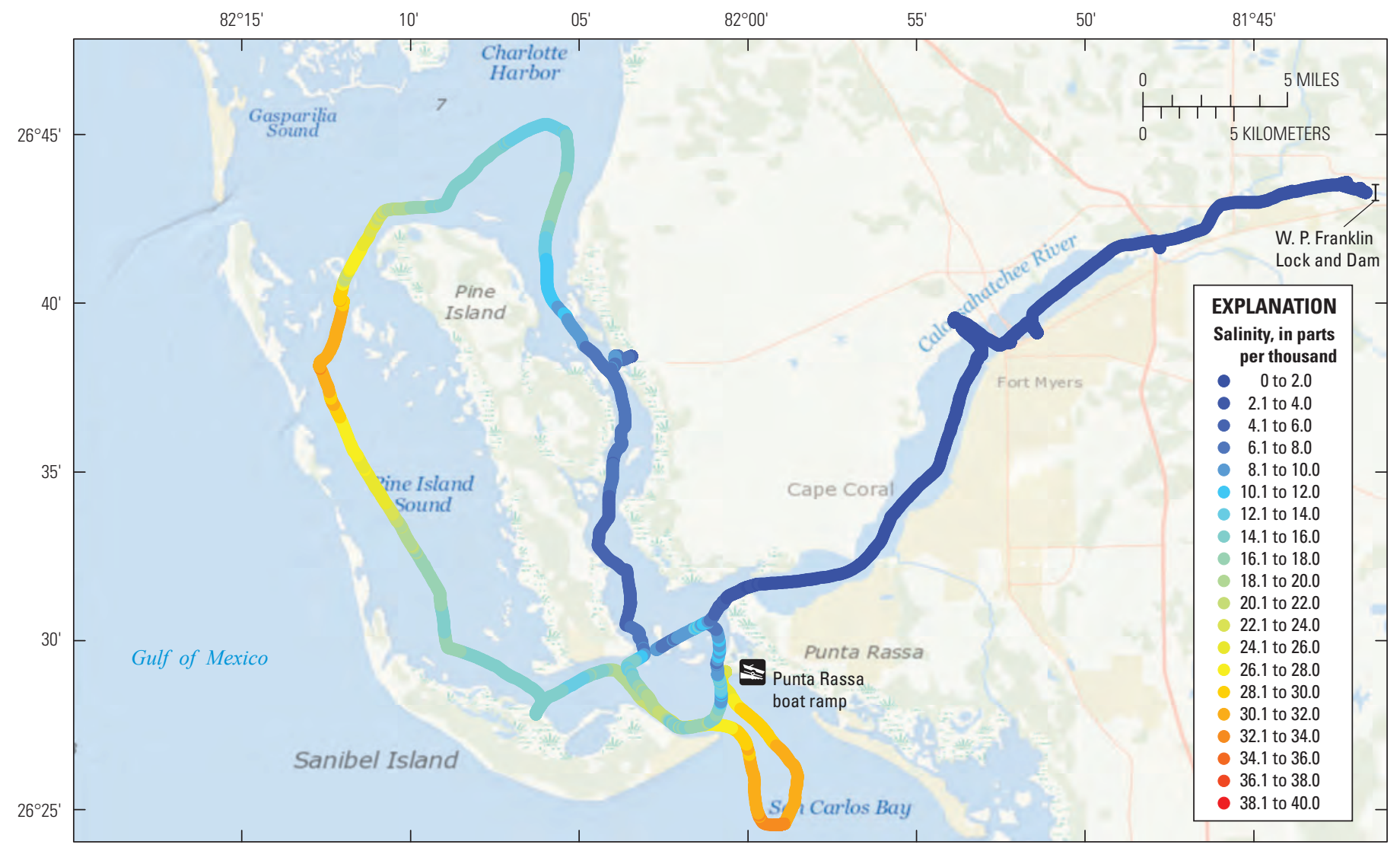

Map image is the intellectual property of Esri and is used herein under license. Copyright (C) 2014 Esri and its licensors. All rights reserved.

Sources: Esri, GEBCO, NOAA, National Geographic, DeLorme, HERE, Geonames.org, and other contributors

Figure 5. Example of salinity-survey data collected along the tidal Caloosahatchee River and downstream estuaries on August 1, 2013. 
Table 1. Area monitoring stations, including location, available data, and period of record.

[USGS, U.S. Geological Survey; ddmmss, degrees, minutes, seconds]

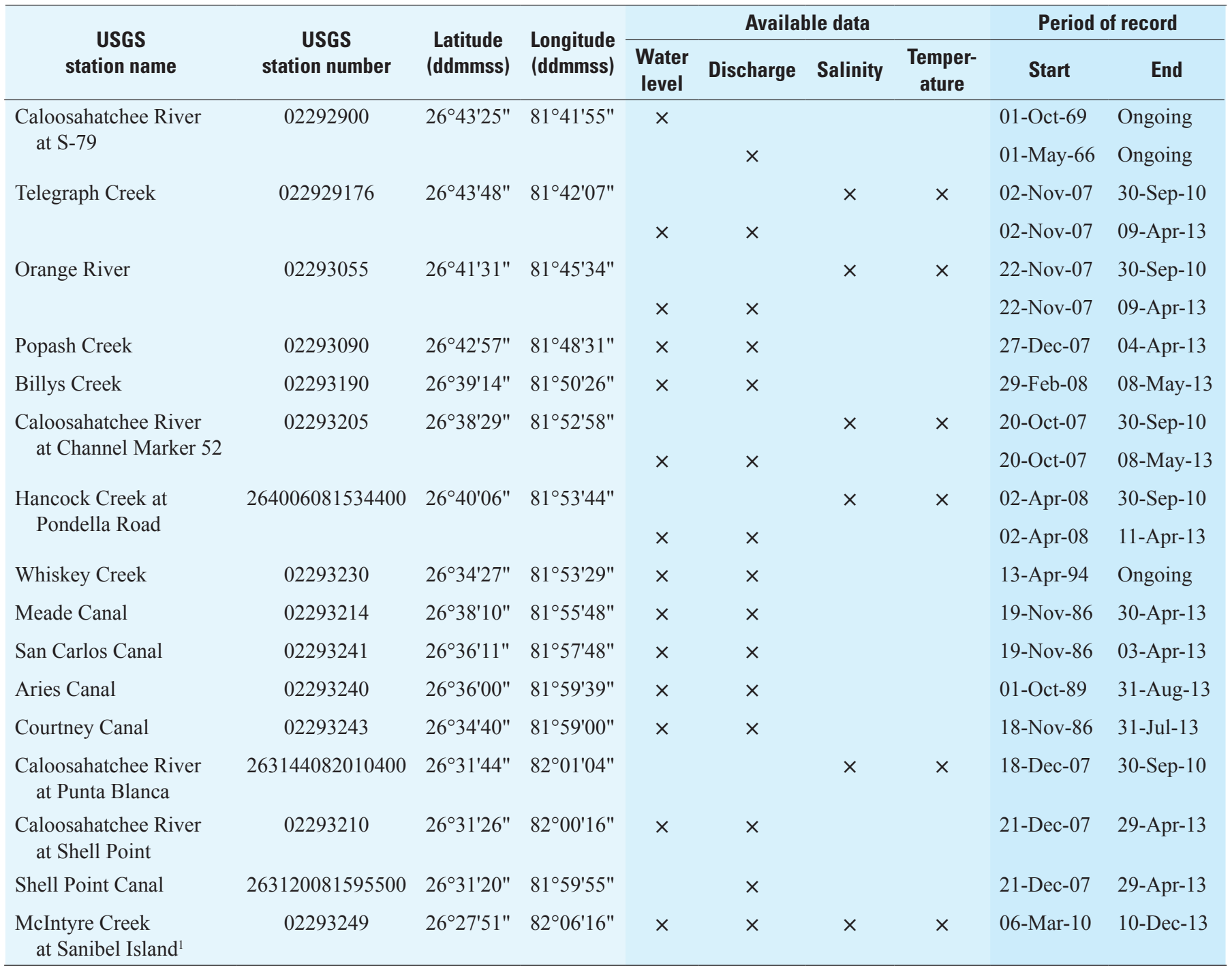

${ }^{1}$ Dissolved oxygen, $\mathrm{pH}$, and turbidity data are also available for this site for the period of record shown.

Levesque, V.A., and Oberg, K.A., 2012, Computing discharge using the index velocity method: U.S. Geological Survey Techniques and Methods, book 3, chapter A23, 148 p., accessed August 19, 2014, at http://pubs.usgs.gov/tm/3a23/.

Rantz S.E., and others, 1982a, Measurement and computation of streamflow: U.S. Geological Survey Water Supply Paper 2175, v. 1-2, 631 p., accessed August 19, 2014, at http://pubs. usgs.gov/wsp/wsp2175/.

Soderqvist, L.E., and Patino, Eduardo, 2010, Seasonal and spatial distribution of freshwater flow and salinity in the Ten Thousand Islands Estuary, Florida, 2007-2009: U.S. Geological Survey Data Series 501, 24 p., accessed August 19, 2014, at http://pubs.usgs.gov/ds/501/.

South Florida Water Management District, 2014, Coastal watersheds, Caloosahatchee River and estuary: South Florida Water Management District Web site accessed August 19, 2014, at http://www.sfwmd.gov/portal/page/portal/xweb\%20protecting\%20and\%20restoring/caloosahatchee\%20strategies.
South Florida Water Management District, Florida Department of Environmental Protection, and Florida Department of Agriculture and Consumer Services, 2009, Caloosahatchee River Watershed Protection Plan: South Florida Water Management District Web site accessed October 30, 2014, at http://www.sfwmd.gov/portal/page/portal/xrepository/sfwmd_ repository_pdf/ne_crwpp_main_123108.pdf

Wagner, R.J., Bougler, R.W., Oblinger, C.J., and Smith, B.A., 2006, Guidelines and standard procedures for continuous water-quality monitors-Station operation, record computation, and data reporting: U.S. Geological Survey Techniques and Methods, book 1, chap. D3, 51 p., accessed August 19, 2014, at http://pubs.usgs.gov/tm/2006/tm1D3/.

\section{For more information, contact:}

Director, USGS Caribbean-Florida Water Science Center 4446 Pet Lane, Suite 108,

Lutz, FL 33559

http//fl.water.usgs.gov 